\title{
Curriculum Review and Revision at the University of Minnesota College of Veterinary Medicine
}

\author{
Margaret V. Root Kustritz — Laura K. Molgaard a Erin Malone
}

\begin{abstract}
Curriculum review is an essential part of ongoing curriculum development, and is a mandate of the American Veterinary Medical Association Council on Education (AVMA COE), the accrediting body of all North American schools and colleges of veterinary medicine. This article describes the steps in curriculum review undertaken by the University of Minnesota College of Veterinary Medicine (UMN CVM) in response to this mandate from the $\mathrm{COE}$ and to a recommendation from a recent collegiate review that was part of a larger university-level strategic planning effort. The challenges of reviewing and revising the curriculum within a short time frame were met by appointing a dedicated curriculum review board and by engaging students and faculty groups, both as focus groups and as specific faculty work sections within disciplines. Faculty voting on the process was very valuable as it permitted the curriculum review board and faculty groups to move ahead knowing there was a process in place for reassessment if most faculty did not agree with recommendations. Consistent support from the dean of the college and other administrators was vital in helping maintain momentum for curriculum review.
\end{abstract}

Key words: accreditation, competency/competencies, curriculum, curriculum review

\section{INTRODUCTION}

Curriculum review is an essential part of ongoing curriculum development, and is a mandate of the American Veterinary Medical Association Council on Education (AVMA COE), the accrediting body of all North American schools and colleges of veterinary medicine. This article describes the steps in curriculum review undertaken by the University of Minnesota College of Veterinary Medicine (UMN CVM) in response to this mandate from the $\mathrm{COE}$ and to a recommendation from a recent collegiate review that was part of a larger university-level strategic planning effort. The UMN CVM had last implemented a new curriculum in 1997. Curricular drift and expansion had since occurred, despite ongoing review by the collegiate Committee on Curriculum and Educational Policy (CCEP). The university undertook a process to prioritize areas for new investment as well as cost-saving strategies. Through this process, groups of collegiate faculty and administrators evaluated our teaching, research, service, and operational endeavors. Curriculum review was identified as a necessary project as a result of that exercise. Steps in curriculum review and revision included

- determination of governance structure;

- definition of the college's mission and values;

- needs assessment;

- definition of specific aims of curriculum review and revision; and

- design of curriculum (scope and sequence) and teaching/learning methodologies.

\section{DETERMINATION OF GOVERNANCE STRUCTURE}

Predetermination of governance structure provides support for curricular review and revision, especially at the midpoint of the project when goals may appear too broad or distant to be reached, and when resistance from faculty members increases. Faculty participation in creation of the governance scheme achieves faculty buy-in early in the process. Members of curriculum review committees should be open to questions, comfortable with give-andtake and management of conflict, able to meet deadlines, able to facilitate decision by consensus, respectful of themselves and others, and able to establish a distance between the overall curricular work and their particular disciplines. $^{\text {a }}$

\section{Curriculum Revision Goals}

As the executive board of the college, the dean and administrative council (department chairs, associate deans, and other senior administrators) appointed members of a specific curriculum review board (CRB, Table 1), and charged them with specific goals and a time line of completion of 2 years. The goals were as follows:

- to ensure appropriate courses available for UMN DVM students and potentially for students at other sites;

- to introduce flexibility in the early part of the curriculum to give students some control over cost; 
Table I: Composition and tasks of the curriculum review board (CRB)

Members

- Faculty facilitator (0.5 FTE)

- Two members from each department, representing tenure-track and clinical-track faculty, basic science, and clinical science

Tasks

- Investigate methodologies for curriculum review and revision in veterinary medicine

- Lead faculty through exercise defining faculty review and acceptance of curricular changes (voting)

- Define overarching goals and competencies

- Ensure alignment with accreditation requirements

- Review pre-clinical and clinical curricular offerings and make recommendations regarding revision

- Consider and evaluate changes in prerequisites, possibility of year-round or 3-year training program, possibility of offset entry times by year, and other innovations

- Regularly communicate with faculty and gather input from faculty, staff, outside constituents, and students

- Lead faculty through one or more approval processes as needed to define curricular changes to be recommended

- to create graduates with entry-level competence and confidence and to provide them with the scientific foundation required for acquisition of discipline or species expertise, including an emphasis on critical thinking that integrates basic science and clinical learning, and appropriate understanding and use of the veterinary literature;

- to create graduates interested in and capable of career paths outside of practice; and

- to decrease cost of curriculum delivery.

\section{Faculty Participation}

Faculty buy-in is a crucial aspect of curriculum review and revision, as the curriculum is within the purview of the faculty. At UMN CVM, participation and governance occurred in three phases. In the first phase, faculty members decided on the process for curriculum review. Faculty voted to adopt the process for curricular review and revision as described, and determined that the final curriculum would be voted on in two steps, one for clinical curriculum offerings and one for pre-clinical curriculum offerings, with majority acceptance. If the majority of faculty members voting did not accept the proposal, the CRB was to start again. In the second phase, members of the CRB led faculty members through the curriculum review. In the third phase, which took place after adoption of the revised curriculum, faculty members who had been identified as course coordinators presented proposed course syllabi to the CCEP and worked with the committee to address any inconsistencies between CRB recommendations and proposed course offerings. In this way, the new curriculum was generated and approved by the faculty rather than imposed upon them.

During this time of review and revision, the existing veterinary curriculum was frozen, with a moratorium on introducing new courses or significant changes in existing courses until the review was complete. The CCEP was not charged with the curriculum review and revision, as this would have required significant effort on the part of faculty members who had been assigned to that committee before such an extensive project was planned. It would also have been unfair to the college, as it would have drawn CCEP members away from the ongoing work of addressing educational policy and student concerns.

\section{DEFINITION OF COLLEGE MISSION/ VALUES}

The curriculum must align with the mission of the college, as mandated by the AVMA COE. ${ }^{1}$ The mission is an overall vision for the graduates of the college. Values statements demonstrate the principles the college will follow to achieve the mission. When considering the mission and values, the college may wish to consider overall teaching values as well. Three categories of teaching have been defined. These include transmission (communicating content), transaction (developing cognitive processes and fostering inquiry), and transformation (developing all aspects of the individual to transform students into professionals learned in the discipline of interest). ${ }^{2}$ Use of these categories in teaching varies across the curriculum, with transformation of the individual into a professional representing the culmination of the curriculum. If the collegiate mission is to be achieved, teaching values must be synchronized with collegiate missions and values.

In the UMN CVM curriculum review, the CRB used the collegiate mission and values statements as touchstones, thus ensuring that no revision would lead away from the college's stated mission. UMN CVM teaching values were created during the review process and were expressed as overarching goals that were agreed upon by faculty, staff, and students. These goals included stimulation of clinical reasoning and problem solving; promotion of retention by use of conscious redundancy and active learning paradigms when appropriate; emphasis on Day One knowledge and abilities; use of relevant assessments; provision of opportunities for active learning, critical thinking, and experiential work in the schedule, and provision of faculty training in the use of these strategies; optimization of core content; attention to sequencing for vertical and horizontal integration; and greater emphasis on health promotion and disease prevention as a dedicated topic area in the curriculum. 


\section{NEEDS ASSESSMENT}

A needs assessment is designed to identify current needs and illuminate gaps between the present curriculum and a preferred curriculum; this assessment is perhaps the most important data-gathering step in curriculum review and revision. It includes both retrospective analysis (what has this curriculum achieved?) and prospective analysis (what do we want our graduates to look like?). Methods used to obtain necessary information-information to perform both the retrospective and prospective analysesmay include seeking advice from other institutions, consulting experts, or consulting some combination of the following: literature reviews; published recommendations from stakeholder groups, professional organizations, or accrediting bodies; curriculum documents; public health statistics and other descriptions of disease prevalence; surveys of practitioners, students, clients, or other stakeholders; and job analysis studies. ${ }^{3-43}$

The sources of information, process for data collection, and uses of information during curriculum review and revision at UMN are shown in Table 2. While valuable information was gathered from various sources, several stood out as providing particularly useful information to guide curriculum reform. Review of the literature helped inform the CRB and provided the CRB and faculty members with evidence to help guide their decisions. Assessment of case load by service in the UMN Veterinary Medical Center was easy to do and was illuminating. It helped verify that the existing set of core clinical experiences was meeting the college's desire for student exposure to a wide range of cases and species. It also helped drive student engagement in the curriculum review process. Student input on the existing and proposed curricula was very valuable, as it is virtually impossible for faculty members and administrators to put themselves in the students' place as novices living the educational experience the college provides. Student input was generally frank and respectful. The CRB and faculty were very responsive to student concerns when considering curricular change. Students also participated in a voluntary workload survey, which provided valuable information about how students actually spend their time in and outside of class. This led to reconsideration of the formula for assigning credits to courses, which is now a better reflection of the amount of time students spend on various kinds of course work. Faculty focus groups were used to encourage faculty engagement and to help the CRB address concerns as they arose, rather than having to backtrack after decisions had been made. Finally, input from external sources, including an educational specialist, veterinary practitioners, and industry partners, helped us stay focused on the goal of educating entry-level veterinarians and helped build connections between the college and these valuable partners.

\section{DEFINITION OF SPECIFIC AIMS OF CURRICULUM REVIEW AND REVISION}

Specific aims that must be addressed in curriculum review and revision are national competency and curriculum requirements; core competencies defined for the specific program; and specific learning objectives and performance indicators to permit harmonization among teaching methodologies, in-class and out-of-class work, and student assessment.

All North American veterinary schools are accredited by the AVMA COE and must be part of a larger university or a system of health professional schools that is accredited regionally. There are 11 accreditation standards, 2 of which have components pertaining to curriculum. Standard 9, "Curriculum," delineates the broad necessities in the 4 years of instruction, and Standard 11, "Outcomes Assessment," includes information on the specific competencies that students from accredited schools must learn. ${ }^{4}$ Other sources used to create and refine competencies for our program included information from the North American Veterinary Medical Education Consortium (NAVMEC), and input from students, faculty, and practitioners gathered during needs assessment. Competencies (technical and non-technical) were set out by year, with extensive input from faculty, staff, and students before these were finalized. A list of competencies is available from the authors upon request.

\section{DESIGN OF CURRICULUM AND TEACHING/LEARNING METHODOLOGIES}

The CRB used the list of competencies by year to generate a draft curriculum. Various models for curricular design were considered, among them a block curriculum, in which systems or themes are covered in blocks of time, with all disciplines participating in that block; a problembased learning model, in which student inquiry guides learning and faculty facilitation ensures that learning objectives are met; a double-helix model, in which strict attention is paid to horizontal and vertical integration in interdisciplinary courses focusing on systems or disciplines; a modular curriculum, in which core and many special study modules permit great individual specialization and study at the learner's pace; and a strict competency-based curriculum, in which detailed performance indicators are identified for all competencies of interest and students progress through the curriculum sequentially after repeated assessment and remediation. The existing systems-based curriculum had undergone significant drift over time such that vertical integration had been lost and the curriculum had become very dense with content. In human medical education, curriculum design is not strongly correlated with student achievement on standardized licensing examinations. ${ }^{45}$ As the CRB could find minimal evidence to support one curricular design over another, they felt free to consider the model they found best for the college as a whole, and not just for the learners.

The CRB chose to present a model proposed by two of the members that was not systems-based but instead progressed from the cellular level to the whole animal. The committee felt that it would be the most helpful model and would require the least overhaul of existing courses, and that it met the goal of helping students achieve competence in basic knowledge and skills and enhanced proficiency in their species or field of interest. ${ }^{46}$ This model 
Table 2: Needs assessment for curriculum revision

\begin{tabular}{ll}
\hline Source & Process \\
\hline $\begin{array}{l}\text { Literature } \\
\text { review }\end{array}$ & $\begin{array}{l}\text { The literature in veterinary and human medicine was } \\
\text { reviewed for information about Day One competencies in } \\
\text { veterinary medicine to ensure proposal of evidence-based } \\
\text { changes. }\end{array}$
\end{tabular}

\begin{tabular}{ll}
\hline Rotation & Information was collected from the past 5 years for \\
enrollment & each rotation regarding number of offerings per year, \\
data & enrollment per offering relative to maximum enrollment \\
& permitted, and track of students enrolled.
\end{tabular}

Assessment of Members of the CRB used the college's electronic medical case load by record system to identify kinds of cases most commonly service record system to identify kinds of cases most commonly
seen in certain clinical services. Students on selected clinical rotations were also asked to track cases seen while on that rotation.

Student Students who apply to the University of Minnesota admissions College of Veterinary Medicine (UMN CVM) are invited to survey complete a survey about admissions processes and their decision to apply to the college, with questions on the influence of the curriculum. Survey responses for the past several years were reviewed.

Use in curriculum review and revision

The curriculum review board (CRB) used this information to help build and refine a list of competencies and to ensure attention to detail regarding definition and inclusion of technical and non-technical competencies.

Data were presented and recommendations made to department chairs regarding decreasing the number of offerings of some rotations and consolidating others. Discussion of these recommendations is ongoing.

Both the faculty review of common presenting concerns and diagnoses and the student case logs showed a good mix of cases across the existing core rotations for each track, suggesting that those track requirements did not require extensive revision.

Prospective students greatly valued the flexibility in the curriculum due to tracking by species or career interest and the possibility of completing dual degree programs, and they were heavily influenced by the strong research presence at UMN. Individuals who had visited the campus spoke well of the student ambassadors and the facilities, affirming our perceptions that we should build on the strengths of facilities and case load in the new curriculum.

Student input on existing and proposed curricula
Current students were encouraged to offer suggestions on the existing curriculum and ideas for revision, either electronically via the curriculum review blog or on a physical wall where comments could be handwritten anonymously.

\section{Student concerns that were most commonly voiced} included the following:

- request for more active and less passive teaching and learning methodologies, including clinical skills training;

- conscious incorporation of redundancy to build skills and knowledge;

- increase in faculty communications and content integration (vertical and horizontal);

- fewer courses to permit internal integration and decreased assessments in the semester;

- flexibility in teaching methodologies to meet student learning styles;

- more emphasis on preventive care and exposure to common disorders; and

- more hands-on surgery training, especially for dogs and cats, and extended orientation to clinics.

The CRB brought these concerns to the faculty and then discussed the faculty responses. These were addressed in design and implementation, and some of this work is ongoing.

Student Student volunteers completed a weekly workload workload inventory to provide specific information about number inventory of hours spent each week in lecture, in laboratory or experiential learning, doing required work outside of class (reading, assignments, group projects), and doing independent study.
Data from workload inventories were used to generate a specific metric for credit hours. This metric was applied to all continuing and new courses in the curriculum to permit the CRB to increase the time available to students for independent study. The metric developed was the following: number of credits $=$ ([lecture / small-group hours $+[1.2][$ laboratory hours] + number of stand-alone online modules][2.5]) / 37.5. The CRB also used this to determine number of credit hours in a given semester; in this curriculum, 24 credits $=\sim 60$ hours of work/week.

The CRB used feedback from these discussions extensively to guide decisions about core courses versus tracked courses in the pre-clinical curriculum.

\footnotetext{
Faculty focus groups Members of the CRB facilitated focus groups of speciesspecific faculty to

- define which competencies were core and which were specific to a given species or career path, and

- identify the most common disorders in their species.

Members of the CRB facilitated focus groups of speciesspecific faculty and private practitioners to determine which rotations were core for a given track and which elective rotations should be offered. Some species groups had completed this work before the curriculum review.
} 
Table 2: Continued

\begin{tabular}{|c|c|c|}
\hline Source & Process & Use in curriculum review and revision \\
\hline $\begin{array}{l}\text { Faculty input on } \\
\text { current and } \\
\text { former curricula }\end{array}$ & $\begin{array}{l}\text { The existing curriculum and the curriculum that preceded } \\
\text { it were posted electronically on the curriculum review } \\
\text { blog and were made available as hard copies. Faculty } \\
\text { members were encouraged to provide the CRB with } \\
\text { strengths and weaknesses of the two, anonymously if they } \\
\text { wished. }\end{array}$ & $\begin{array}{l}\text { The most common faculty concerns included the } \\
\text { following: } \\
\text { - ensuring faculty autonomy in teaching methodologies } \\
\text { used; } \\
\text { - ensuring efficient use of faculty time for teaching; } \\
\text { - building on existing strengths in the curriculum and } \\
\text { identifying gaps in the curriculum; } \\
\text { - ensuring standards for accreditation are met; and } \\
\text { - ensuring attention to increasing responsibilities, } \\
\text { especially in the transition to a new curriculum, } \\
\text { necessitating double teaching by some faculty members. } \\
\text { The most common faculty suggestions included the } \\
\text { following: } \\
\text { - more case-based learning and more learning based on } \\
\text { presenting problems instead of discrete infectious or } \\
\text { noninfectious agents of disease; } \\
\text { - recommendations for the clinical year that were unique } \\
\text { to their species interest or career; and } \\
\text { - ongoing oversight of the new curriculum to prevent } \\
\text { disintegration, drift, and continual addition of content. } \\
\text { The CRB acted on recommendations that were appropriate } \\
\text { (evaluating for gaps and ensuring accreditation standards } \\
\text { were met). Others were addressed during design and } \\
\text { implementation. Faculty recommendations regarding the } \\
\text { clinical year were used extensively by the CRB in consider- } \\
\text { ing track-specific offerings. }\end{array}$ \\
\hline
\end{tabular}

Colleagues The head of the CRB interviewed individuals from veterinary schools and schools of pharmacy that had recently undergone curricular reform, specifically asking about process and pitfalls, and members of the CRB spoke to colleagues at other veterinary schools regarding contact/credit hours in various disciplines.
The primary themes that emerged were the need for strong collegiate governance and faculty acceptance and engagement throughout the process. Clear identification of monetary and human resources is valuable. Colleagues also spoke of not making change for the sake of change, and of carefully considering all implications when making recommendations for major change. Finally, the most common recommendation was allotting time to meet the challenges of faculty resistance to curricular change and to ensure curricular change can take place alongside ongoing faculty work. It was suggested that a full-time administrator with appropriate staff support should lead the curriculum review and revision. The CRB worked extensively with department chairs, and the leader of the CRB met regularly with the Associate Dean of Academic and Student Affairs and the CVM's dean. Faculty communications included a continuously updated blog (no longer available), a wall where hard copies of various materials were posted and comments solicited, regular presentations at department and full faculty meetings, open admittance to regularly scheduled CRB meetings, and specific meetings with representative faculty groups as requested.

Practitioners Members of the Minnesota Veterinary Medical Association (MVMA) were surveyed to help define which competencies were required by entry-level practitioners in the various species and to help us better identify common disorders. Demographic information was collected to ensure balance in participation by species focus, state of licensure, number of years in practice, and type of practice. Seventy-seven practitioners completed the survey.
Overall, the responses suggested to the CRB that practitioners believe we must do all we can to provide enough core experiences to train general practitioners. The data collected in this survey did not provide clear direction regarding competencies by track or career choice. We discussed creating and distributing a more targeted survey to better determine needs by track, but decided that this was not likely to yield significant results without undue effort. Information from practitioners regarding common disorders was shared with speciesspecific faculty groups for discussion. 
Table 2: Continued

\begin{tabular}{|c|c|c|}
\hline Source & Process & Use in curriculum review and revision \\
\hline $\begin{array}{l}\text { Standardized } \\
\text { testing }\end{array}$ & $\begin{array}{l}\text { Limited North American Veterinary Licensing Examination } \\
\text { (NAVLE) performance data are available to schools and } \\
\text { were evaluated to determine any general disciplinary } \\
\text { strengths or weaknesses of UMN CVM students. }\end{array}$ & $\begin{array}{l}\text { Too little detail was provided to guide curriculum review } \\
\text { and revision. }\end{array}$ \\
\hline $\begin{array}{l}\text { External } \\
\text { educational } \\
\text { specialist }\end{array}$ & $\begin{array}{l}\text { We approached an educational specialist at a medical } \\
\text { school to provide input on our plan of work. }\end{array}$ & $\begin{array}{l}\text { The external expert encouraged us to move quickly } \\
\text { toward defining competencies by year in the curriculum, } \\
\text { and to solidify our overarching goals. She gave good advice } \\
\text { regarding active and self-directed teaching and learning } \\
\text { methodologies that was included in implementation of the } \\
\text { new curriculum. She also helped us think through how } \\
\text { best to identify gaps and how to build in conscious } \\
\text { redundancy. }\end{array}$ \\
\hline $\begin{array}{l}\text { Industry } \\
\text { representatives }\end{array}$ & $\begin{array}{l}\text { Banfield, the largest corporate veterinary practice in the } \\
\text { US, presented information to the college specifically about } \\
\text { companion animal preventive care and changing needs in } \\
\text { the veterinary profession. This was mirrored by other } \\
\text { sources, including the AVMA, American Animal Hospital } \\
\text { Association, Zoetis (formerly Pfizer), and other large } \\
\text { industry partners. }\end{array}$ & $\begin{array}{l}\text { The CRB used these data to gather information about } \\
\text { preventive care offerings throughout the existing } \\
\text { curriculum and advisability of offering a course in preven- } \\
\text { tive care early in the new curriculum to provide students } \\
\text { with a framework for learning. }\end{array}$ \\
\hline
\end{tabular}

also met criteria described in research suggesting that the most effective curricula are those with a well-defined and carefully structured core, and fewer, very specific electives. ${ }^{47}$

After deciding on the structure of the curriculum, the CRB chose first to specifically review the clinical year (deliberate backward design). At the UMN CVM, students can select a specific track in their senior year. Tracks available before the curriculum review were small animal, food animal, equine, mixed animal, and interdisciplinary. The interdisciplinary track was originally intended for research-focused or dual-degree students and required students to identify and work with a specific faculty mentor to ensure adequacy of experiences in the clinical year of training. Over time, this track became a popular general track because of its flexibility, and the CCEP reported concern that students with traditional career goals were choosing this track simply for that flexibility. The CRB aimed to better define the purpose of the tracks and reevaluated track requirements, using data generated during needs assessment and input from faculty, staff, and students. The result was that the five tracks were maintained, with small animal, food animal, and equine tracks virtually unchanged. The mixed animal track was made slightly more flexible and mentoring made more deliberately available to students in this track. It was made clear that students going into any form of practice, including zoo/exotic/wildlife and pathology, would be in the mixed track, not the former interdisciplinary track. That track was renamed the public health/research track with the purpose of using it for students with non-clinical career goals, and the existing mentoring requirement was maintained (Table 3).

The revised clinical curriculum at the UMN CVM was accepted by vote of the full faculty in February 2012, with fairly equal representation from all departments. The final vote was $90 \%$ yes, $6 \%$ no, and $4 \%$ abstain. The revised clinical curriculum was implemented with the class of 2014.

The CRB then turned its attention to the pre-clinical curriculum. For didactic (pre-clinical) coursework, one primary goal was to ensure students were no longer required to participate in many small courses, which promoted overlapping examinations and increased students' tendency to binge and purge rather than to gain a deeper understanding of the material. Caution was exercised not to create "mega-courses," as it was our experience from the past that courses larger than 5 credits had an undue effect on GPA, making students focus on these courses at the expense of others. A second goal was to provide a mix of information and experience for the students, and to give them the time needed to work through the material in the method most appropriate to their learning styles by providing more time for independent study. ${ }^{47} \mathrm{~A}$ draft didactic curriculum was generated, with benchmarks of no more than 20 hours per week of lecture and 10-15 hours per week of laboratory, and no more than 28 credits per semester (for a resulting 60-hour workweek based on student workload inventory).

Faculty members from each discipline group met with members of the CRB to confirm core content in proposed courses (defining scope) and discuss placement within the overall curriculum (defining sequence). When the CRB asked faculty members as a group whether they wished to self-define contact time/credit hours or to be given guidelines, they requested the latter. The CRB generated an estimate for contact time/credit hours based on proposed course content and data from the existing curriculum. Faculty members in a given group or discipline were provided with the estimate for contact time/credit hours, and given information regarding which courses in the existing curriculum were being consolidated or 
Table 3: Track requirements for clinical rotations

\begin{tabular}{|c|c|c|c|c|}
\hline Small animal & Food animal & Equine & Mixed animal & Dual degree \\
\hline Orientation to clinics & Orientation to clinics & Orientation to clinics & Orientation to clinics & Orientation to clinics \\
\hline $\begin{array}{l}4 \text { SAM (I SAM-A + } 3 \\
\text { SAM-B) }\end{array}$ & $\begin{array}{l}\text { I LAM + } 3 \text { LAM or } \\
\text { DOFC or SWPHI or } \\
\text { Camelid or Feedlot or } \\
\text { SmRum or RAOls with } \\
\text { ambulatory service }\end{array}$ & $\begin{array}{l}3 \text { LAM + I LAM or SAM } \\
\text { or RAOI }\end{array}$ & 4 medicines & 4 medicines \\
\hline $\begin{array}{l}2 \text { surgeries total: } \\
\text { I SAS + I ESAS or } \\
\text { shelter or shelter RAOI }\end{array}$ & $\begin{array}{l}2 \text { LAS or I LAS + I Bov } \\
\text { sx or RAOI }\end{array}$ & 2 LAS & 2 surgeries & 2 surgeries \\
\hline $\begin{array}{l}\text { I public health } \\
\text { I necropsy } \\
\text { I anesthesiology } \\
\text { I clinical labs } \\
\text { I radiology }\end{array}$ & $\begin{array}{l}\text { I public health } \\
\text { I necropsy } \\
\text { I anesthesiology } \\
\text { I clinical labs } \\
\text { I radiology or imaging } \\
\text { RAOI }\end{array}$ & $\begin{array}{l}\text { I public health } \\
\text { I necropsy } \\
\text { I anesthesiology } \\
\text { I clinical labs } \\
\text { I radiology or radiology } \\
\text { RAOI }\end{array}$ & $\begin{array}{l}\text { I public health } \\
\text { I necropsy } \\
\text { I anesthesiology } \\
\text { I clinical labs } \\
\text { I radiology }\end{array}$ & $\begin{array}{l}\text { I public health } \\
\text { I necropsy } \\
\text { I anesthesiology } \\
\text { I clinical labs } \\
\text { I radiology }\end{array}$ \\
\hline $\begin{array}{l}2 \text { GP + I Derm or } \\
\text { Derm RAOI + I } \\
\text { Dent + I ECC }\end{array}$ & DOFC +6 FA rotations & $\begin{array}{l}\text { I ELamP }+ \text { I } \\
\text { EqAmb }+ \text { EqThl }+3 \\
\text { equine rotations }\end{array}$ & $\begin{array}{l}\text { I GP + } 5 \text { FA, Eq or SA } \\
\text { rotations }\end{array}$ & \\
\hline $\begin{array}{l}3-5 \text { externships* or } \\
\text { RAOls }\end{array}$ & $\begin{array}{l}3-5 \text { externships* or } \\
\text { RAOls }\end{array}$ & $\begin{array}{l}3-5 \text { externships* or } \\
\text { RAOls }\end{array}$ & $\begin{array}{l}3-5 \text { externships* or } \\
\text { RAOls }\end{array}$ & \\
\hline $5-7$ elective rotations & $3-5$ elective rotations & $3-5$ elective rotations & $3-5$ elective rotations & $\begin{array}{l}\text { I } 5 \text { elective rotations, } \\
\text { externships, * or RAOls }\end{array}$ \\
\hline 27 total & 27 total & 27 total & 27 total & 27 total \\
\hline
\end{tabular}

reorganized into the course in question, and where the CRB thought this new course should appear in the curricular sequence. The goals for consolidated courses were as follows:

1. Ensure the proposed consolidated course meets the needs of the students.

2. Define core content for that course.

3. Determine necessary contact time/credit hours.

4. Define leadership (course coordinator role) within the group for each proposed course.

To guide determination of what was core content, the CRB met with various faculty groups and generated the following criteria to be considered for each major topic area, assignment, and assessment tool in a given course:

- Is this material used frequently in veterinary practice or alternative veterinary career paths?

- Is this material necessary for immediate use (as in emergency situations)?

- Is this material necessary for students to achieve licensure and/or USDA accreditation?

- Is provision of this material necessary for $\mathrm{COE}$ accreditation?

- Does requiring this reading/assignment/examination or other assessment accurately reflect course learning objectives and promote critical thinking and problem solving?

Members of the CRB facilitated these course meetings and posted minutes and supporting documents on a website available to all faculty members. The committee regularly reminded group members of pending tasks until a complete draft was available for consideration. As the faculty groups completed their tasks, information was brought back to the CRB to be reconciled with original recommendations. The faculty thus generated a pre-clinical curriculum (Table 4).

This revision met the goal of decreasing lecture contact time and increasing hands-on or active learning. Lecture contact time decreased over the first six semesters of the curriculum from 2,764 hours to 2,182 hours, a $21.1 \%$ decrease, or a change from 30.7 to 24.2 scheduled hours of lecture time per week. Laboratory contact time increased by $10.8 \%$, with a change from 7.4 to 8.2 scheduled hours of laboratory per week. Other changes in the revision included the following:

- Anatomy was increased from one to two semesters to better meet student needs regarding knowledge of basic anatomy, including association with function. 
Table 4: Faculty-generated pre-clinical curriculum

\begin{tabular}{|c|c|}
\hline Course & Hours (lecture/laboratory) and [credits] \\
\hline \multicolumn{2}{|l|}{ Year I Fall } \\
\hline Anatomy I & $24 / 99[5]$ \\
\hline Clinical Skills I & $10 / 20[1]$ \\
\hline Microscopic Anatomy & $26 / 54[4]$ \\
\hline Veterinary Biochemistry, Nutrition, and Genetics & $45 / 0[3]$ \\
\hline Physiology I & $69 / 15[5]$ \\
\hline Professional Development I & $15 / 0[1]$ \\
\hline Gopher Orientation and Leadership Experience (GOALe) & $15 / 0[1]$ \\
\hline Foundations of Interprofessional Communication and Collaboration & $15 / 0[1]$ \\
\hline Total & $219(14.6 \mathrm{hr} / \mathrm{wk}) / 188(12.5 \mathrm{hr} / \mathrm{wk})[2 \mathrm{I}]$ \\
\hline \multicolumn{2}{|l|}{ Year I Spring } \\
\hline Anatomy II & $17 / 66[3]$ \\
\hline Clinical Skills II & $10 / 20[1]$ \\
\hline Physiology II & $75 / 0[5]$ \\
\hline Professional Development II & $25 / 10[1]$ \\
\hline GOALe & $15 / 0[1]$ \\
\hline Critical Scientific Reading & $15 / 0[1]$ \\
\hline Immunology & $30 / 0[2]$ \\
\hline Basic Pathology & $32 / 21[3]$ \\
\hline Agents of Disease I & $55 / 0[4]$ \\
\hline Preventive Medicine & $53 / 0[4]$ \\
\hline Total & $327(2 \mathrm{l} .8 \mathrm{hr} / \mathrm{wk}) / \mathrm{I} I 7$ (7.8 hr/wk) [25] \\
\hline \multicolumn{2}{|l|}{ Year 2 Fall } \\
\hline Agents of Disease II & $60 / 0[4]$ \\
\hline Pharmacology I & $48 / 0[3]$ \\
\hline Systemic Pathology & $58 / 30[5]$ \\
\hline Clinical Pathology I & $23 / 3[2]$ \\
\hline Clinical Skills III & $10 / 20[1]$ \\
\hline Clinical Epidemiology & $24 / 0[2]$ \\
\hline Public Health & $30 / 0[2]$ \\
\hline Small Animal Medicine I & $27 / 0[2]$ \\
\hline Diagnostics Laboratory & $0 / 60[2]$ \\
\hline Total & $280(18.6 \mathrm{hr} / \mathrm{wk}) / \mathrm{I} / 3(7.5 \mathrm{hr} / \mathrm{wk})$ [23] \\
\hline \multicolumn{2}{|l|}{ Year 2 Spring } \\
\hline Small Animal Medicine II & 68/27 [5] \\
\hline Small Animal Surgery I & 29/17 [3] \\
\hline Large Animal Medicine I & $39 / 4[3]$ \\
\hline Large Animal Surgery I & $35 / 0[2]$ \\
\hline Veterinary Imaging I & $25 / 42[3]$ \\
\hline Clinical Skills IV & $10 / 20[1]$ \\
\hline Clinical Pathology II & $23 / 3[2]$ \\
\hline Pharmacology II & $64 / 0[4]$ \\
\hline Professional Development III & $30 / 0[2]$ \\
\hline Non-Traditional Pets & $16 / 3[1]$ \\
\hline Avian Core & $25 / 8[2]$ \\
\hline Total & 364 (24.3 hr/wk)// 24 (8.3 hr/wk) [28] \\
\hline
\end{tabular}


Table 4: Continued

\begin{tabular}{lc}
\hline Course & Hours (lecture/laboratory) and [credits] \\
\hline Year 3 Fall & \\
Small Animal Medicine III & $74 / 4[5]$ \\
Small Animal Surgery II and Anesthesia & $38 / 23[3]$ \\
Large Animal Medicine II & $78 / 0[5]$ \\
Large Animal Surgery II & $22 / 0[1.5]$ \\
Veterinary Imaging II & $25 / 42[3]$ \\
Comparative Specialties (dermatology/ophthalmology/behavior) & $45 / 10[3]$ \\
Comparative Theriogenology & $40 / 30[4]$ \\
Clinical Skills V & $10 / 20[1]$ \\
Professional Development IV & $30 / 0[2]$ \\
Total & $362(24.1 \mathrm{hr} / \mathrm{wk}) / 129(8.6 \mathrm{hr} / \mathrm{wk})[27.5]$ \\
\hline
\end{tabular}

Year 3 Spring

Students would be required to take at least 12 credits in Year 3 Spring, which is shorter than the other semesters by 2-3 weeks, and would have to have taken at least 4 credits in problems courses by the end of this semester. Required courses by track would be as follows:

Track
Equine
Food animal
Mixed
Research/public health
Small animal

Required Y3S courses

Orientation to clinics, Equine I, Equine II, Equine Problems

Orientation to clinics, Food Animal I, Food Animal II, Obstetrics, Food Animal Problems

Orientation to clinics, Equine I, Food Animal I, Small Animal I, Obstetrics

Orientation to clinics, Equine I, Food Animal I, Small Animal I

Orientation to clinics, Small Animal I, Small Animal II, Small Animal Problems

Electives

Advanced Clinical Epidemiology, Avian Medicine and Surgery, Clinical Correlations, Integrative Medicine, Introduction to Swine Production Medicine, Medical Management of Zoo Animals, Neonatology, Opportunities in International and Cultural Immersion, Public Health Issues and Veterinary Medicine Opportunities, Topics in Zoo Animal Medicine, Zoo and Wildlife Rounds

- Histology and organology were consolidated into microscopic anatomy.

- The required genetics course was consolidated into biochemistry, and the basics of nutrition were added to that course.

- Physiology was increased from one to two semesters and information from neurobiology and reproductive biology was included in that course.

- The professional development series and animal populations were reconfigured and spread throughout the curriculum to ensure timely provision of information. For example, communications training was moved later in the curriculum and student safety training moved earlier.

- Bacteriology, virology, and parasitology were consolidated into two semesters of agents of disease, to be taught as core content followed by case-based integrated content.

- Pharmacology and toxicology were consolidated and the pharmacology content re-sequenced.

- The systems-based courses offered in the spring of year 2 and the fall of year 3 were consolidated into larger medicine, surgery, and specialties courses.
- Veterinary imaging content was re-sequenced to provide vertical integration with medicine and surgery.

- A preventive medicine course was added in the spring of year 1 to expose students to basic preventive medicine concepts that can be reinforced at preceptor visits and in later coursework.

- The bacteriology laboratory was replaced with a comprehensive diagnostics laboratory in which students practice principles of laboratory management, hematology, chemistry and serology, clinical microbiology, urinalysis, and parasitology.

The new curriculum at the UMN CVM was accepted by vote of the full faculty in March 2013, with fairly equal representation from all departments. The final vote was $78 \%$ yes, $12 \%$ no, and $10 \%$ abstain. It was decided that the new pre-clinical curriculum would be rolled in, with the class of 2017 beginning in the new curriculum and the classes of 2014-2016 completing their training in the existing curriculum. After several classes have completed the revised curriculum, we will address and report on outcomes including student competence for entry-level practice, student ability in clinical decision making, extent of vertical and horizontal integration throughout the curriculum, and cost-effectiveness of the curriculum. 


\section{DISCUSSION}

University and college mandates for greater efficiency and the $\mathrm{COE}^{\prime}$ s mandate for regular curriculum review lead the UMN CVM to undertake an extensive review and subsequent revision of the curriculum. The review began in March 2011, and the new curriculum was accepted by faculty vote in March 2013 and introduced for the firstyear class in fall 2013 (class of 2017). The classes of 2014, 2015, and 2016 completed their education in the former curriculum as the new curriculum was rolled in by year; this ensured that no student would be disadvantaged by losing opportunities to work through all materials and experiences. The challenges of reviewing and revising the curriculum within a short time frame were met by appointing a dedicated review board (the CRB) and by engaging students and faculty groups, both as focus groups and as specific faculty work sections within disciplines. Faculty voting on the process was very valuable as it permitted the CRB and faculty groups to move ahead knowing there was a process in place for reassessment if most faculty members did not agree with recommendations. Consistent support from the dean of the college and other administrators was vital in helping maintain momentum for curriculum review.

In general, the new curriculum decreases direct student contact time, leaving more time for independent study; it ensures student access to material determined to be core for all students while still permitting advanced study by species within the tracked portion of the curriculum; it enhances opportunities for integration through consolidation of courses and oversight by a dedicated curriculum coordinator; it improves opportunities for distributed student learning by decreasing number and frequency of examinations; and hopefully it decreases cost of delivery of the curriculum, with the goal of slowing the rise of tuition costs. Appointing a curriculum coordinator greatly aided the implementation and maintenance of the new curriculum. The coordinator monitors progress on curricular goals and specifically provides course coordinators and instructors with support for efforts in active learning and integration. The roles of the CRB concluded as implementation began, with the CCEP taking on integration and ongoing review of courses in the new curriculum, as is appropriate based on accreditation requirements for function of a collegiate curriculum committee. The college has already made some changes in the new curriculum based on student and faculty feedback and outcomes assessment including student workload concerns. No curriculum is static and any new curriculum is just a springboard for the next round of review and revision as colleges seek continual improvement.

\section{ACKNOWLEDGMENTS}

The authors wish to acknowledge the contributions of Drs. David Brown, Michael Conzemius, Daniel Feeney, John Fetrow, and James Mickelson.

\section{NOTE}

a I. Broyles and C. Cartwright, course notes for the online course "Curriculum," Masters in Medical Education and Leadership, University of New England, November 14, 2013

\section{REFERENCES}

1 American Veterinary Medical Association (AVMA). Accreditation policies and procedures of the AVMA Council on Education [Internet]. Schaumburg, IL: AVMA; 2016 [cited 2017 Jun 2]. Available from: https:// www.avma.org/ProfessionalDevelopment/Education/ Accreditation/Colleges/Documents/coe_pp.pdf.

2 Miller JP, Seller W. Curriculum: perspectives and practice. Toronto: Copp Clark Pitman; 1990.

3 Bass EB. Step 1: problem identification and general needs assessment. In: Kern DE, Thomas PA, Hughes MT, editors. Curriculum development for medical education. Baltimore, MD: The Johns Hopkins University Press; 2009. p. 10-26.

4 Bachynsky EA, Dale VH, Kinnison T, et al. A survey of the opinions of recent veterinary graduates and employers regarding early career business skills. Vet Rec. 2013;172(23):604. https://doi.org/10.1136/ vr.101376. Medline:23633459

5 Butler DG. Employer and new graduate satisfaction with new graduate performance in the workplace within the first year following convocation from the Ontario Veterinary College. Can Vet J. 2003;44(5):380-91. Medline:12757129

6 Abood SK, Siegford JM. Student perceptions of an animal-welfare and ethics course taught early in the veterinary curriculum. J Vet Med Educ. 2012;39(2):13641. https://doi.org/10.3138/jvme.0911.093R1.

Medline:22718000

7 Kieves NR, Roark AW, Sparks TK. Business education in veterinary schools: the potential role of the Veterinary Business Management Association. J Vet Med Educ. 2007;34(5):678-82. https:// doi.org/10.3138/ jvme.34.5.678. Medline:18326781

8 Lloyd JW, Fingland R, Arighi M, et al. Satellite teaching hospitals and public-private collaborations in veterinary medical clinical education. J Vet Med Educ. 2008;35(1):43-7. https://doi.org/10.3138/jvme.35.1.043. Medline:18339955

9 Main DCJ, Thornton P, Kerr K. Teaching animal welfare science, ethics, and law to veterinary students in the United Kingdom. J Vet Med Educ. 2005;32(4):505-8. https://doi.org/10.3138/jvme.32.4.505. Medline:16421835

10 Coe JB, Adams CL, Bonnett BN. A focus group study of veterinarians' and pet owners' perceptions of the monetary aspects of veterinary care. J Am Vet Med Assoc. 2007;231(10):1510-8. https://doi.org/10.2460/ javma.231.10.1510. Medline:18020992

11 Coe JB, Adams CL, Bonnett BN. A focus group study of veterinarians' and pet owners' perceptions of veterinarian-client communication in companion animal practice. J Am Vet Med Assoc. 2008;233(7):107280. https://doi.org/10.2460/javma.233.7.1072. Medline: 18828715

12 Coe JB, Adams CL, Bonnett BN. Prevalence and nature of cost discussions during clinical appointments in companion animal practice. J Am Vet Med Assoc. 2009;234(11):1418-24. https://doi.org/10.2460/ javma.234.11.1418. Medline:19480621

13 Collins GH, Taylor RM. Attributes of Australasian veterinary graduates: report of a workshop held at the 
Veterinary Conference Centre, Faculty of Veterinary Science, University of Sidney, January 28-19, 2002. J Vet Med Educ. 2002;29(2):71-2. https://doi.org/10.3138/ jvme.29.2.71. Medline:12143022

14 Danielson JA, Wu TF, Fales-Williams AJ, et al. Predictors of employer satisfaction: technical and non-technical skills. J Vet Med Educ. 2012;39(1):62-70. https:// doi.org/10.3138/jvme.0711.072R. Medline:22433741

15 Dawson SD, Miller T, Goddard SF, et al. Impact of outcome-based assessment on student learning and faculty instructional practices. J Vet Med Educ. 2013;40(2):128-38. https:// doi.org/10.3138/jvme.1112100R. Medline:23709109

16 Doucet MY, Vrins A. The importance of knowledge, skills, and attitude attributes for veterinarians in clinical and non-clinical fields of practice: a survey of licensed veterinarians in Quebec, Canada. J Vet Med Educ. 2009;36(3):331-42. https://doi.org/10.3138/jvme/014. Medline:19861721

17 Doucet MY, Vrins A. Use of alumni and employer surveys for internal quality assurance of the DVM program at the University of Montreal. J Vet Med Educ. 2010;37(2):178-89. https://doi.org/10.3138/ jvme.37.2.178. Medline:20576908

18 Dysart LM, Coe JB, Adams CL. Analysis of solicitation of client concerns in companion animal practice. J Am Vet Med Assoc. 2011;238(12):1609-15. https://doi.org/ 10.2460/javma.238.12.1609. Medline:21671816

19 Fogelberg K, Farnsworth CC. Faculty and students' selfassessment of client communication skills and professional ethics in three veterinary medical schools. J Vet Med Educ. 2009;36(4):423-8. https://doi.org/ 10.3138/jvme.36.4.423. Medline:20054081

20 Frenk J, Chen L, Bhutta ZA, et al. Health professionals for a new century: transforming education to strengthen health systems in an interdependent world. Lancet. 2010;376(9756):1923-58. https:// doi.org/10.1016/S01406736(10)61854-5. Medline:21112623

21 Greenfield CL, Johnson AL, Klippert L, et al. Employerbased outcomes assessment of recent graduates and comparison with performance during veterinary school. J Am Vet Med Assoc. 1997;211(7):842-9. Medline:9333082

22 Greenfield CL, Johnson AL, Schaeffer DJ. Frequency of use of various procedures, skills, and areas of knowledge among veterinarians in private small animal exclusive or predominant practice and proficiency expected of new veterinary school graduates. J Am Vet Med Assoc. 2004;224(11):1780-7. https://doi.org/ 10.2460/javma.2004.224.1780. Medline:15198262

23 Greenfield CL, Johnson AL, Schaeffer DJ. Influence of demographic variables on the frequency of use of various procedures, skills, and areas of knowledge among veterinarians in private small animal exclusive or predominant practice and proficiency expected of new veterinary school graduates. J Am Vet Med Assoc. 2005;226(1):38-48. https://doi.org/10.2460/ javma.2005.226.38. Medline:15646571

24 Hill LN, Smeak DD, Lord LK. Frequency of use and proficiency in performance of surgical skills expected of entry-level veterinarians by general practitioners. J Am
Vet Med Assoc. 2012;240(11):1345-54. https://doi.org/ 10.2460/javma.240.11.1345. Medline:22607603

25 Jaarsma DA, Dolmans DH, Scherpbier AJ, et al. Preparation for practice by veterinary school: a comparison of the perceptions of alumni from a traditional and an innovative veterinary curriculum. J Vet Med Educ. 2008;35(3):431-8. https://doi.org/ 10.3138/jvme.35.3.431. Medline:19066361

26 Kanji N, Coe JB, Adams CL, et al. Effect of veterinarianclient-patient interactions on client adherence to dentistry and surgery recommendations in companionanimal practice. J Am Vet Med Assoc. 2012;240(4):42736. https://doi.org/10.2460/javma.240.4.427. Medline:22309015

27 Kleine LJ, Terkla DG, Kimball G. Outcomes assessment at Tufts University School of Veterinary Medicine. J Vet Med Educ. 2002;29(1):32-5. https://doi.org/10.3138/ jvme.29.1.32. Medline:11932838

28 Klingborg DJ, Klingborg J. Talking with veterinary clients about money. Vet Clin North Am Small Anim Pract. 2007;37(1):79-93. https:// doi.org/10.1016/ j.cvsm.2006.09.007. Medline:17162113

29 Kogan LR, Goldwaser G, Stewart SM, et al. Sources and frequency of use of pet health information and level of confidence in information accuracy, as reported by owners visiting small animal veterinary practices. J Am Vet Med Assoc. 2008;232(10):1536-42. https://doi.org/ 10.2460/javma.232.10.1536. Medline:18479246

30 Kogan LR, McConnell SL, Schoenfeld-Tacher R. Response of a veterinary college to career development needs identified in the KPMG LLP study and the executive summary of the Brakke study: a combined MBA/DVM program, business certificate program, and curricular modifications. J Am Vet Med Assoc. 2005;226(7):1070-6. https://doi.org/10.2460/ javma.2005.226.1070. Medline:15825731

31 Lane IF, Bogue EG. Faculty perspectives regarding the importance and place of nontechnical competencies in veterinary medical education at five North American colleges of veterinary medicine. J Am Vet Med Assoc. 2010;237(1):53-64. https:// doi.org/10.2460/ javma.237.1.53. Medline:20590495

32 Martin EA. Managing client communication for effective practice: what skills should veterinary graduates have acquired for success? J Vet Med Educ. 2006;33(1):45-9. https://doi.org/10.3138/jvme.33.1.45. Medline:16767637

33 McKenzie B. Practitioner survey. Ridgeland, MS: Evidence-Based Veterinary Medicine Association; 2011.

34 Miller RB, Hardin LE, Cowart RP, et al. Practitionerdefined competencies required of new veterinary graduates in food animal practice. J Vet Med Educ. 2004;31(4):347-65. https://doi.org/10.3138/ jvme.31.4.347. Medline:15551229

35 Rhind SM, Baillie S, Kinnison T, et al. The transition into veterinary practice: opinions of recent graduates and final year students. BMC Med Educ. 2011;11(1):64. https://doi.org/10.1186/1472-6920-11-64. Medline:21939551

36 Root Kustritz MV, Chenoweth PJ, Tibary A. Efficacy of training in theriogenology as determined by a survey of veterinarians. J Am Vet Med Assoc. 2006;229(4):514-21. 
https://doi.org/10.2460/javma.229.4.514.

Medline:16910848

37 Root Kustritz MV, Molgaard LK, Tegzes JH. Frequency of interactions between veterinarians and other professionals to guide interprofessional education. J Vet Med Educ. 2013;40(4):370-7. https://doi.org/10.3138/ jvme.0413-065R1.

38 Rossi J. Bioethics in veterinary medicine. Annual Conference of the Society for Theriogenology; 2012 Aug 20-25; Baltimore, MD.

39 Self DJ, Wolinsky FD, Baldwin DC Jr. The effect of teaching medical ethics on medical students' moral reasoning. Acad Med. 1989;64(12):755-9. https:// doi.org/10.1097/00001888-198912000-00014. Medline:2590358

40 Shaw JR, Adams CL, Bonnett BN, et al. Veterinarianclient-patient communication during wellness appointments versus appointments related to a health problem in companion animal practice. J Am Vet Med Assoc. 2008;233(10):1576-86. https://doi.org/10.2460/ javma.233.10.1576. Medline:19014290

41 Tait J. The evolving workplace for new veterinary graduates. Can Vet J. 2002;43(6):469-71. Medline:12058575

42 Vandeweerd J-M, Vandeweerd S, Gustin C, et al. Understanding veterinary practitioners' decisionmaking process: implications for veterinary medical education. J Vet Med Educ. 2012;39(2):142-51. https:// doi.org/10.3138/jvme.0911.098R1. Medline:22718001

43 Sutphen SM, Cibula DA, Morrow CB, et al. Evaluation of a preventive medicine curriculum: incorporating a case-based approach. Am J Prev Med. 2003;24(4 Suppl):90-4. https:// doi.org/10.1016/S07493797(03)00027-8. Medline:12744985

44 American Veterinary Medical Association (AVMA). Accreditation [Internet]. Schaumburg, IL: AVMA; 2015 [cited 2013 Nov 1]. Available from: https:// www.avma.org/ProfessionalDevelopment/Education/ Accreditation/Pages/default.aspx.
45 Hecker K, Violato C. How much do differences in medical schools influence student performance? A longitudinal study employing hierarchical linear modeling. Teach Learn Med. 2008;20(2):104-13. https:// doi.org/10.1080/10401330801991915. Medline:18444195

46 Latucca LR, Stark JS. Shaping the college curriculum: academic plans in context. San Francisco: Jossey-Bass; 2009.

47 Barnett R, Coate K. Engaging the curriculum in higher education. Maidenhead, UK: Society for Research into Higher Education, Open University Press; 2005.

\section{AUTHOR INFORMATION}

Margaret V. Root Kustritz, DVM, PhD, DACT, MMEd, is professor of Theriogenology and Assistant Dean of Education, Department of Veterinary Clinical Sciences, University of Minnesota College of Veterinary Medicine, St. Paul, MN 55I08 USA. Email: rootk00I@umn.edu. Her research interests include determination of optimal age for gonadectomy of dogs and cats and innovative teaching strategies.

Laura K. Molgaard, DVM, is Associate Dean of Academic and Student Affairs, Department of Veterinary Clinical Sciences, and Assistant Professor, Department of Veterinary Population Medicine, University of Minnesota College of Veterinary Medicine, St. Paul, MN 55I08 USA. Her research interests include selection for and development of non-technical competencies, technologyenhanced learning, and outcomes assessment.

Erin Malone, DVM, PhD, DACVS, is Professor of Large Animal Surgery and Curriculum Coordinator, Department of Veterinary Population Medicine, University of Minnesota College of Veterinary Medicine, St. Paul, MN 55I08 USA. Her research interests include evaluation of teaching methodologies to enhance retention. 